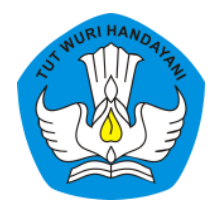

Page: $39-58$

\title{
Pengembangan Multimedia Teks Wawanrembug Berbasis Blended Learning pada Siswa Kelas VIII
}

\author{
Sutriono Hariadi \\ Sekolah Menengah Pertama Negeri 8 Kota Probolinggo \\ Contributor Email: sutrionoh@gmail.com
}

Published: Mar 30, 2020

Article Url: http:/ / ojsdikdas.kemdikbud.go.id/index.php/didaktika/article/view/125

\begin{abstract}
The learning media that will be developed based on technology is the students' base upload skills in the Wawanrembug text. So it is necessary to support learning media to be able to achieve optimal results. This study aims to develop Multimedia Text Wawanrembug Based on Blended Learning and test the effectiveness of the media. This development research method uses the Four-D model namely Define, Design, Develop, Disseminate and the quality of the media is measured through validity, practicality, and effectiveness. The results of the research analysis concluded that multimedia developed in the form of html-based media, android applications, and categorized powerpoint applications is feasible to use. The average for the experimental class is 82.5 and the control class is 77.9. The percentage of feasibility of the developed media is $83 \%$. This multimedia development is very easy to make because it only has Ms. application. Power point. Multimedia developed combined with Blended Learning (using Google Site) can improve student learning outcomes. Thus, the Multimedia Development of Wawanrembug Text Based on Blended Learning in Class VIII Students can be used as a learning medium for students to learn how to upload Wawanrembug Text.
\end{abstract}

Keywords: Multimedia Development, Blended Learning 


\begin{abstract}
Abstrak
Media pembelajaran yang akan dikembangkan berbasis teknologi yaitu keterampilan Unggah-Ungguh Basa siswa dalam teks Wawanrembug. Sehingga diperlukan penunjang media pembelajaran untuk dapat meraih hasil yang optimal. Penelitian ini bertujuan mengembangkan Multimedia Teks Wawanrembug Berbasis Blended Learning serta menguji keefektifan media. Metode penelitian pengembangan ini menggunakan model Four-D yakni Define, Design, Develop, Disseminate dan kualitas media diukur melalui kevalidan, kepraktisan, dan keefektifan. Hasil analisis penelitian didapatkan simpulan bahwa multimedia yang dikembangkan berupa media berbasis html, aplikasi android, dan aplikasi powerpoint terkategorikan layak digunakan. Ratarata untuk kelas eksperimen adalah 82,5 dan kelas kontrol adalah 77,9. Persentase kelayakan dari media yang dikembangkan adalah sebesar 83\%. Pengembangan multimedia ini sangat mudah dibuat karena hanya berbekal aplikasi Ms. Powerpoint. Multimedia yang dikembangkan dipadukan dengan proses pembelajaran Blended Learning (menggunakan Google Site) mampu meningkatkan hasil belajar siswa. Dengan demikian, Pengembangan Multimedia Teks Wawanrembug Berbasis Blended Learning pada Siswa Kelas VIII dapat dijadikan sebagai media pembelajaran bagi siswa untuk pembelajaran unggah-ungguh basa Teks Wawanrembug.
\end{abstract}

Kata Kunci: Pengembangan Multimedia, Blended Learning

\title{
A. Pendahuluan
}

Abad XXI ditandai oleh perkembangan dan pemanfaatan Teknologi Informasi dan Komunikasi (TIK), termasuk dalam proses pembelajaran. Sekolah diharapkan mampu menyiapkan siswa memasuki abad XXI. Hal tersebut dikuatkan oleh (J. Rotherdam \& Willingham, 2009) bahwa seorang siswa yang sukses kelak bergantung pada kecakapan abad XXI sehingga siswa wajib belajar untuk menguasai kecakapan tersebut.

Guru sebagai ujung tombak pembelajaran di kelas diharapkan mampu meningkatkan profesionalitas. Dalam Kurikulum 2013, peran dan fungsi guru adalah membuat pembelajaran menjadi bermakna dan menciptakan suasana belajar yang menyenangkan bagi siswa. Peran guru tersebut terimplementasikan dalam fungsinya sebagai fasilitator dan kolaborator pembelajaran. Siswa diharapkan berperan aktif dalam proses pembelajaran. Hal tersebut sejalan dengan isi (Peraturan Pemerintah Nomor 19 Tahun 2005 Standar Pendidikan Nasional, 2005) Pasal 19 Ayat 
1, yaitu sekolah melaksanakan pembelajaran melalui kegiatan motivasi, inspiratif, dan interaktif. Selain itu, haruslah berupa kegiatan yang menantang, siswa untuk berperan aktif, kreatif, dan mandiri sesuai dengan bakat, minat, dan perkembangan fisik siswa.

Dalam (Undang-Undang Nomor 20 Tahun 2003 Sistem Pendidikan Nasional), pemakaian bahasa daerah diatur untuk melengkapi bahasa Indonesia yang diwajibkan dalam penyelenggaraan pendidikan di Indonesia. Pembelajaran bahasa Jawa sebagai muatan lokal merupakan upaya pelestarian bahasa daerah di jalur pendidikan. Dalam (Peraturan Gubernur Jawa Timur Nomor 19, 2014), ruang lingkup pembelajaran bahasa Jawa adalah siswa memiliki keterampilan komunikasi bahasa Jawa dan menumbuhkembangkan apresiasi karya sastra dan budaya Jawa.

Materi yang selalu ada di pembelajaran Bahasa Jawa adalah Unggah-Ungguh Basa. Pembelajaran bahasa Jawa memuat ajaran budi pekerti luhur dan pembelajaran ini berbeda dengan pembelajaran bahasa lain karena bahasa Jawa memiliki unggah-ungguh basa (Adipitoyo, 2018). Pendapat ini diperkuat yang menyatakan bahwa pembelajaran bahasa adalah bagian dari budaya (Fishman, 2000). Dari dua pendapat tersebut, dapat disimpulkan bahwa pembelajaran bahasa Jawa, khususnya materi unggah-ungguh basa merupakan hal yang penting. Untuk itu, diperlukan sebuah pembelajaran yang menarik agar siswa dapat benar-benar memahami dan mengaplikasikan unggah-ungguh basa dalam kehidupannya. Salah satu teks yang memuat materi unggah-ungguh adalah Teks Wawanrembug Kelas VIII.

Permasalahan yang muncul saat pembelajaran Bahasa Jawa di SMPN 8 Kota Probolinggo adalah kesulitan siswa memahami materi. Berdasarkan hasil observasi, ditemukan bahwa mayoritas siswa merupakan masyarakat pendalungan. Minimnya media pembelajaran dan tiadanya buku teks. Jumlah jam pelajaran yang hanya 2 JP. Siswa dalam belajar juga kurang antusias, tidak fokus, dan cenderung ramai sendiri. Dari hasil penilaian, diketahui bahwa hasil belajar rata-rata masih berada di bawah. Dampak khususnya pada materi unggah-ungguh basa Teks 
Wawanrembug, proses pembelajaran dan pencapaian hasil tujuan pembelajaran tidak berjalan.

Permasalahan yang telah diuraikan tersebut harus segera diselesaikan. Upaya pemecahan masalah oleh guru adalah membuat inovasi pembelajaran, khususnya media. Media pembelajaran yang akan dikembangkan ini berbasiskan teknologi karena siswa zaman sekarang dekat sekali dengan teknologi. Dalam meningkatkan keterampilan Unggah-Ungguh Basa siswa dalam teks Wawanrembug, diperlukan penunjang media pembelajaran untuk dapat meraih hasil yang optimal. Tujuan pembuatan media pembelajaran berbasis teknologi ini adalah meningkatkan aktivitas siswa dalam proses belajar dan menumbuhkan kreativitas siswa dalam berbahasa Jawa.

Berdasarkan paparan masalah dan dilakukan analisis terhadap penyebab masalah dalam pembelajaran, guru perlu untuk merancang pembelajaran yang menarik agar siswa dapat mengimplementasikan penggunaan Bahasa Jawa sesuai dengan unggah-ungguh basa pada Teks Wawanrembug. Adapun pemecahan masalah yang dapat direncanakan adalah melaksanakan pembelajaran Bahasa Jawa dengan mengembangkan dan menerapkan media berbasis teknologi yang dapat membantu siswa mencapai tujuan pembelajaran. Media tersebut adalah pengembangan Multimedia Teks Wawanrembug Berbasis Blended Learning. Tujuan penggunaan media ini adalah untuk memudahkan siswa dalam memahami, menggunakan, dan berkreasi berbahasa Jawa sesuai dengan unggah-ungguh basa pada materi Teks Wawanrembug. Penggunaan media ini diharapkan, keterampilan siswa dalam menggunakan Bahasa Jawa sesuai dengan unggah-ungguh basa meningkat dengan penanda tuntasnya hasil belajar.

Inovasi pembelajaran pada karya ini adalah pada kebaruan penggabungan berbagai media pembelajaran dengan model pembelajaran blended learning. Multimedia yang dihasilkan dalam karya inovasi ini meliputi produk media powerpint, media html, dan media aplikasi android. Informasi materi yang ada dalam berbagai media tersebut akan 
dapat membuat siswa mengonstruksi pemahaman dengan pendampingan guru. Blended learning yang digunakan mengacu pada Web Centric Course. Hal ini dimaksudkan lebih mudah dalam kontrol kepada siswa. Beberapa hal itu yang menjadi pembeda pada karya inovasi ini dengan penelitian sebelumnya.

Adapun tujuan dari penelitian pengembangan ini adalah menghasilkan dan mendeskripsikan Multimedia Teks Wawanrembug Berbasis Blended Learning yang memenuhi aspek pengembangan media dan aspek materi, menguji keefektifan Multimedia Teks Wawanrembug Berbasis Blended Learning yang memenuhi aspek pengembangan media dan aspek materi dan dapat meningkatkan keterampilan Teks Wawanrembug siswa.

\section{B. Metode}

Adapun rancangan karya inovasi ini dilakukan dengan prosedur penelitian pengembangan Model 4D yang dikembangkan oleh (Thiagarajan, 1974). Model pengembangan $4 \mathrm{D}$ ini terdiri atas empat tahap pengembangan, yaitu define (pendefinisian); design (perancangan); develop (pengembangan); dan desseminate (penyebarluasan). Pada tahap pendefinisian dilakukan dengan analisis awal, yaitu mereview artikel-artikel hasil penelitian yang terkait dengan media pembelajaran, analisis siswa dan guru untuk mengetahui karakteristik kebutuhan, analisis konsep dengan melakukan kajian terhadap referensi, dan analisis tujuan pada analisis aspek pemahaman keterampilan Unggah-Ungguh Basa Teks Wawanrembug yang dikembangkan. Pada tahap perancangan dilakukan pengumpulan teks, pengolahan teks, penyajian materi sesuai struktur yang telah ditetapkan, dan pembuatan ilustrasi pendukung yang bertujuan untuk merancang prototipe media Unggah-Ungguh Basa Teks Wawanrembug. Pada tahap pengembangan dilakukan penyempurnaan media dengan uji produk, revisi, dan uji keefektifan di lapangan. Pada tahap penyebarluasan dilakukan membagikan media kepada siswa dan berbagi hasil pengembangan dalam forum MGMPS dan MGMP Bahasa Jawa. 


\section{Hasil dan Pembahasan}

Dalam bagian ini, disajikan data hasil validasi dan hasil uji coba Multimedia Teks Wawanrembug berbasis Blended Learning. Data hasil validasi meliputi validasi dari ahli media dan ahli materi. Untuk data hasil uji coba, didapatkan dari hasil angket siswa dan uji efektivitas media.

\section{Data Hasil Uji Validasi Ahli Media}

Berkaitan dengan validasi kepada ahli media, aspek yang diujikan adalah aspek rekayasa perangkat lunak dan tampilan visual dan audio. Ahli media dipilih dari dosen desain visual dan guru mata pelajaran TIK yang memiliki kompetensi di bidang media pembelajaran. Berikut ini, akan dipaparkan data hasil uji validasi oleh ahli media.

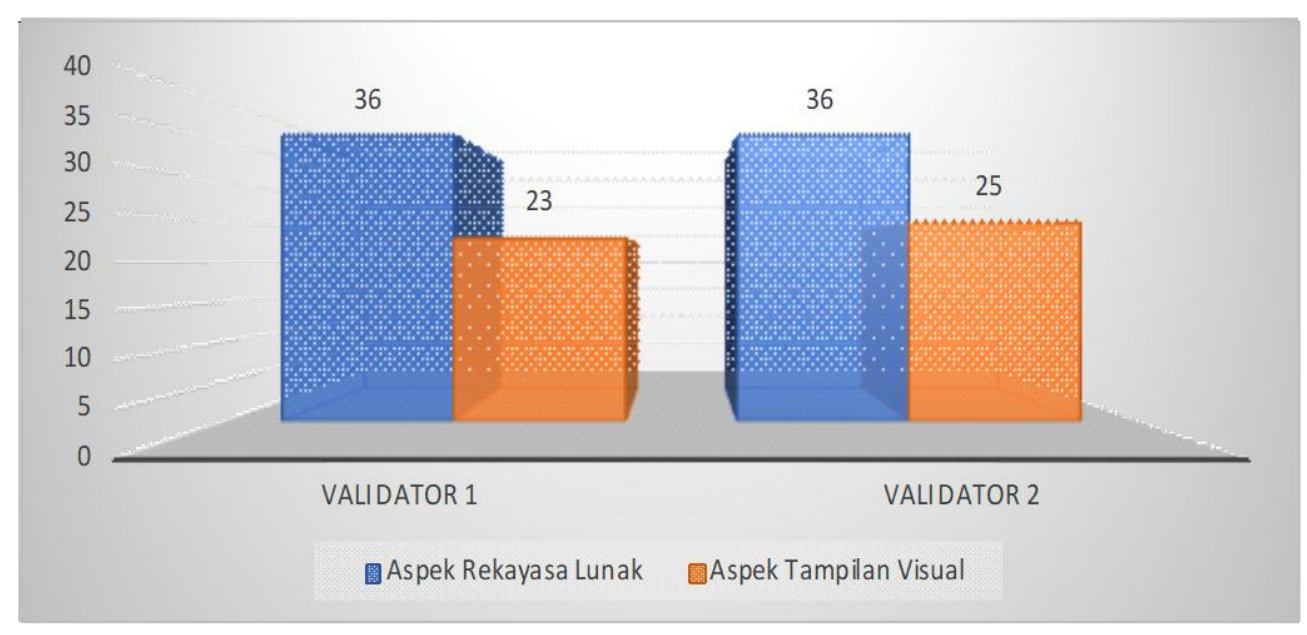

Diagram 1.

\section{Penyajian Data Hasil Uji Validasi Ahli Media}

\section{Data Hasil Uji Validasi Ahli Materi}

Berkaitan dengan validasi kepada ahli materi, aspek yang diujikan adalah aspek isi, penyajian, dan bahasa. Ahli materi dipilih dari guru mata pelajaran Bahasa Jawa dan Pengawas pelajaran Bahasa Jawa yang memiliki kompetensi di bidang materi pembelajaran Bahasa Jawa. Berikut ini, akan dipaparkan data hasil uji validasi oleh ahli materi. 


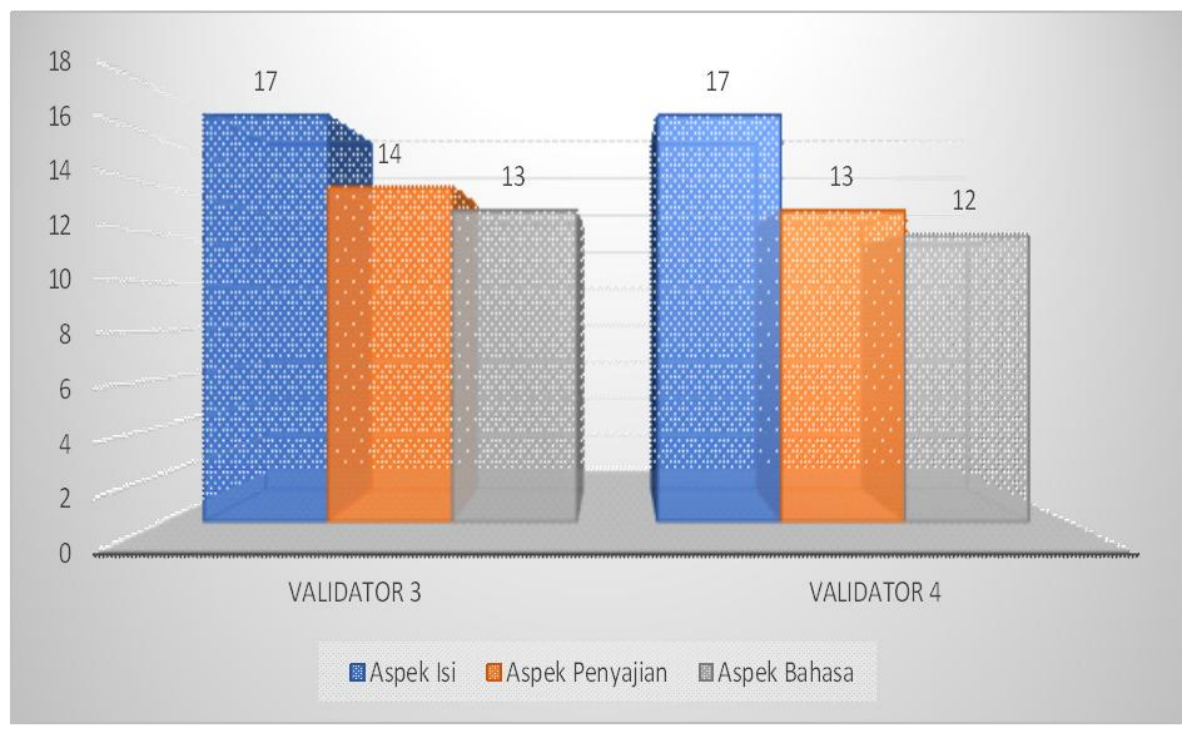

\section{Diagram 2.}

Penyajian Data Hasil Uji Validasi Ahli Materi

\section{Data Hasil Uji Coba Media}

Penyajian data hasil uji coba terbagi atas dua kegiatan, yaitu uji keefektifan media dan pengisian angket oleh siswa. Berikut ini sajian data hasil uji coba keefektifan media yang meliputi deskripsi data, uji prasyarat data, dan uji beda penggunaan media.

\section{a. Deskripsi Data}

Kegiatan uji keefektifan produk dilakukan dengan menggunakan desain quasi eksperimen, yakni pretes-posttest non equivalen control grup design. Desain ini berarti menggunakan kelas kontrol dan kelas eksperimen. Baik kelas kontrol maupun kelas eksperimen diberi perlakuan. Kelas kontrol diberi perlakuan dengan menggunakan bahan ajar buku siswa, sedangkan kelas eksperimen diberi perlakuan menggunakan Multimedia Teks Wawanrembug berbasis Blended Learning. Kelas yang dijadikan sebagai kontrol adalah kelas 8.1, sedangkan kelas 
yang dijadikan eksperimen adalah kelas 8.5. Kedua kelas tersebut merupakan kelas 8 di SMPN 8 Kota Probolinggo.

Data penelitian uji keefektifan dikumpulkan melalui instrumen penelitian yang diberikan pada saat prates dan pascates di kelas kontrol dan kelas eksperimen. Jumlah siswa kelas kontrol dan eksperimen yang mengikuti pra-tes dan pasca-tes adalah 52 siswa. Adapun hasil data distribusi frekuensi skor prates dan pascates unggah-ungguh basa Teks Wawanrembug siswa kelas kontrol dapat dilihat pada Diagram 3 berikut ini.

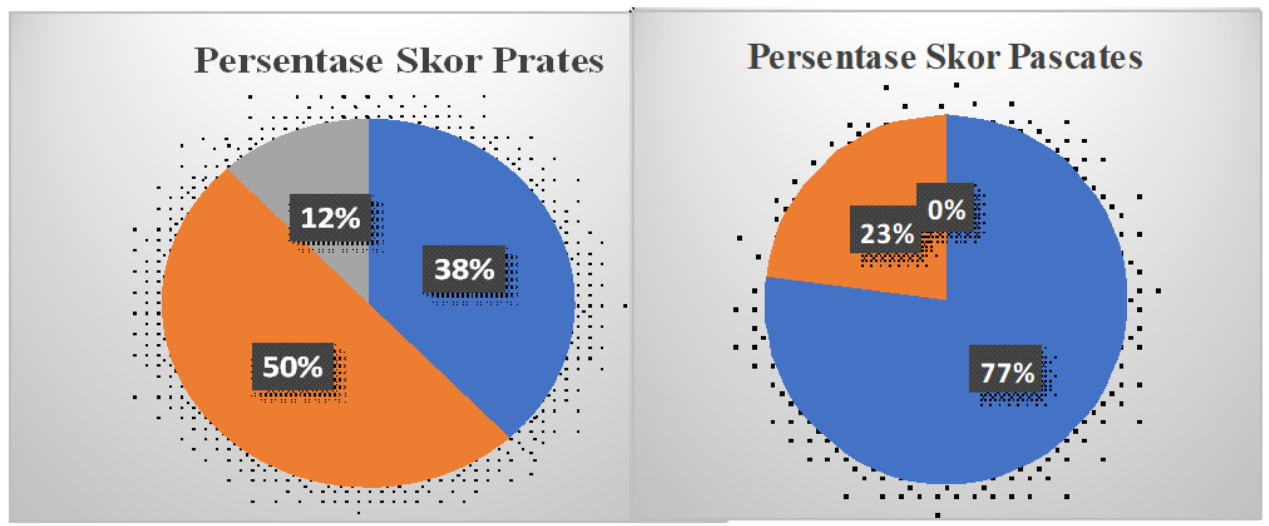

Diagram 3.

Data Distribusi Persentase Skor Prates dan Pascates Unggah-Ungguh Basa Teks Wawanrembug Kelas Kontrol (8.1)

\section{Keterangan :}

\section{Kriteria A: 80-100 \\ Kriteria B: 60-79 \\ Kriteria C: 40-59}

Berdasarkan data pada Diagram 3 tentang hasil tes unggah-ungguh basa siswa, diperoleh data rata-rata kelas prates siswa adalah 76. Setelah diberi perlakuan dengan menggunakan bahan ajar buku siswa terjadi peningkatan saat diukur pada pascates dengan nilai rata-rata 78 . Diketahui pada saat pretes, siswa berkemampuan rendah sebanyak 3 siswa atau $12 \%$, siswa berkemampuan sedang sebanyak 13 siswa atau $50 \%$, dan siswa berkemampuan tinggi sebanyak 10 siswa atau $38 \%$. Nilai terendah prates adalah 50 dan nilai tertinggi adalah 90 . 
Setelah diberi perlakuan dengan menggunakan bahan ajar buku siswa, hasil keterampilan unggah-ungguh basa Teks Wawanrembug siswa mengalami peningkatan. Peningkatan tersebut dapat dilihat dari adanya 0 siswa yang berkemampuan rendah, 6 siswa atau 23\% berkemampuan sedang, dan 20 siswa atau $77 \%$ berkemampuan tinggi. Nilai terendah pascates adalah 57 dan nilai tertinggi adalah 90.

Adapun hasil data distribusi frekuensi skor prates dan pascates unggah-ungguh basa siswa kelas eksperimen dapat dilihat pada Diagram 4 berikut ini.

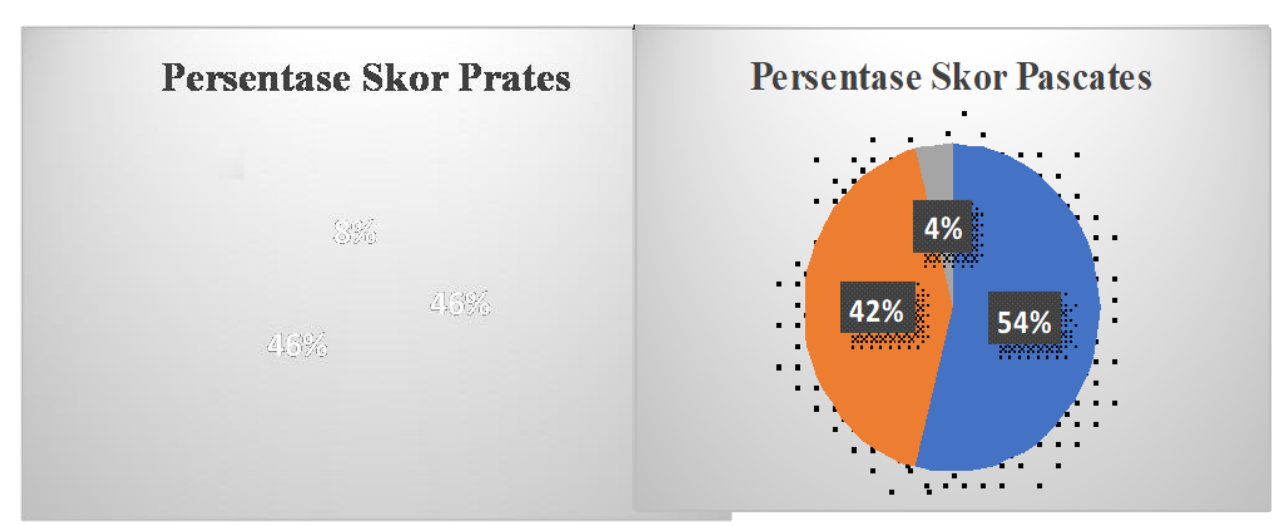

Diagram 4.

\section{Data Distribusi Persentase Skor Prates dan Pascates Kelas Eksperimen (8.5)}

Berdasarkan data pada Diagram 4 tentang hasil tes unggah-ungguh basa Teks Wawanrembug siswa, diperoleh data rata-rata kelas prates siswa adalah 74. Setelah diberi perlakuan dengan menggunakan Multimedia Teks Wawanrembug berbasis Blended Learning terjadi peningkatan saat diukur pada pascates dengan nilai rata-rata 82,5. Diketahui pada saat pretes, siswa berkemampuan rendah sebanyak 2 siswa atau $8 \%$, siswa berkemampuan sedang sebanyak 12 siswa atau 46\%, dan siswa berkemampuan tinggi sebanyak 12 siswa atau $46 \%$. Nilai terendah prates adalah 50 dan nilai tertinggi adalah 90 .

Setelah diberi perlakuan dengan menggunakan Multimedia Teks Wawanrembug berbasis Blended Learning, hasil keterampilan unggah-ungguh 
basa siswa mengalami peningkatan. Peningkatan tersebut dapat dilihat dari adanya 1 siswa atau $4 \%$ berkemampuan rendah, 11 siswa atau $42 \%$ berkemampuan sedang, dan 14 siswa atau 54\% berkemampuan tinggi. Nilai terendah pascates adalah 73 dan nilai tertinggi adalah 93.

\section{b. Uji Prasyarat Analisis Data}

Sebelum melakukan uji beda untuk mengetahui keefektifan media, dilakukan terlebih dulu uji normalitas dan uji homogenitas. Berikut ini akan dijabarkan prosedur kegiatan untuk memenuhi syarat ketiga, yaitu (1) uji normalitas prates kelas kontrol (8.1), (2) uji normalitas prates kelas eksperimen (8.5), (3) uji normalitas pascates kelas kontrol (8.1), (4) uji normalitas pascates kelas eksperimen (8.5), (5) uji homogenitas prates kelas kontrol (8.1) dan kelas eksperimen (8.5), dan (6) uji homogenitas pascates kelas kontrol (8.1) dan kelas eksperimen (8.5).

\section{Tabel 1.}

Hasil Uji Normalitas Prates Kelas Kontrol (8.1)

dan Kelas Eksperimen (8.5)

\begin{tabular}{llrr}
\hline \multicolumn{5}{c}{ One-Sample Kolmogorov-Smirnov Test } \\
\hline & & $\begin{array}{c}\text { Unstandardized } \\
\text { Residual (8.1) }\end{array}$ & $\begin{array}{c}\text { Unstandardized } \\
\text { Residual (8.5) }\end{array}$ \\
\hline $\mathrm{N}$ & Mean & 26 & 26 \\
\hline Normal & & .0000000 & .0000000 \\
\hline Parameters & Std. & 7.57706728 & 7.55602344 \\
& Deviation & .123 & .141 \\
\hline Most Extreme & Absolute & .090 & .119 \\
\cline { 2 - 4 } Differences & Positive & -.123 &. .141 \\
\cline { 2 - 4 } & Negative & .625 & .719 \\
\hline Kolmogorov-Smirnov Z & .830 & .679 \\
\hline Asymp. Sig. (2-tailed) & & \\
\hline a. Test distribution is Normal. & & \\
\hline
\end{tabular}


Tabel 2.

Hasil Uji Normalitas Pascates Kelas Kontrol (8.1)

dan Kelas Eksperimen (8.5)

\begin{tabular}{llrr}
\hline \multicolumn{4}{c}{ One-Sample Kolmogorov-Smirnov Test } \\
\hline & & $\begin{array}{c}\text { Unstandardized } \\
\text { Residual (8.1) }\end{array}$ & $\begin{array}{c}\text { Unstandardized } \\
\text { Residual (8.5) }\end{array}$ \\
\hline $\mathrm{N}$ & Mean & .0000000 & 26 \\
\hline Normal & & .0000000 \\
Parameters & Std. & 7.53068221 & 7.49240274 \\
& Deviation & .123 & .153 \\
\hline Most Extreme & Absolute & .123 & .145 \\
\cline { 2 - 4 } Differences & Positive & -.116 & -.153 \\
\cline { 2 - 4 } & Negative & .625 & .782 \\
\hline Kolmogorov-Smirnov Z & .829 & .574 \\
\hline Asymp. Sig. (2-tailed) & & \\
\hline
\end{tabular}

a. Test distribution is Normal.

Dalam uji homogenitas, diketahui dasar pengambilan keputusan dalam uji ini adalah jika nilai signifikani kurang dari 0,05 maka dikatakan bahwa varian dari beberapa populasi data tidak sama atau tidak homogen. Sebaliknya, jika nilai signifikani lebih besar dari 0,05 maka dikatakan bahwa varian dari beberapa populasi data adalah sama atau homogen.

Berikut ini Tabel 3 dijabarkan hasil uji homogenitas prates dan pascates kelas kontrol (8.1) dan kelas eksperimen (8.5).

Tabel 3.

Hasil Uji Homogenitas Prates Kelas Kontrol (8.1) dan Kelas Eksperimen (8.5)

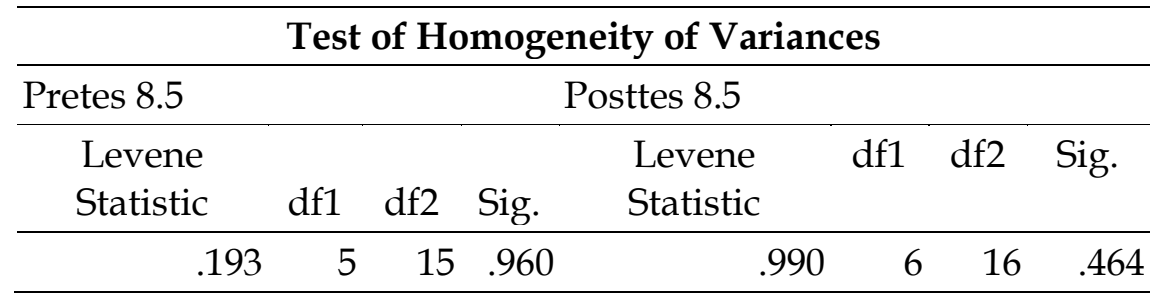


c. Uji Beda Penggunaan Multimedia Teks Wawanrembug berbasis Blended Learning

Dalam pengujian ini, ada dua hipotesis yang diajukan. Hipotesis tersebut diajukan untuk menguji perbedaan rata-rata nilai kelas kontrol dan kelas eksperimen. Kelas kontrol memakai bahan ajar buku siswa, sedangkan kelas eksperimen memakai Multimedia Teks Wawanrembug berbasis Blended Learning. Hipotesis pertama (Ho), yaitu tidak ada perbedaan signifikan ratarata nilai antara kelas kontrol dan kelas eksperimen. Hipotesis kedua $\left(\mathrm{H}_{1}\right)$, yaitu ada perbedaan signifikan rata-rata nilai antara kelas kontrol dan kelas eksperimen. Kriteria pengambilan keputusan mengacu pada ketentuan jika $p$ $>$ 0,05 maka Ho diterima. Sebaliknya, jika $p<0,05$ maka Ho ditolak (Hasan \& Iqbal, 2013). Berikut ini Tabel 3.4 dijabarkan hasil statistika uji beda kelas kontrol (8.1) dan kelas eksperimen (8.5).

Tabel 4 .

Hasil Statistika Uji Beda Kelas Kontrol (8.1) dan Kelas Eksperimen (8.5)

\begin{tabular}{llllrr}
\hline \multicolumn{6}{c}{ Group Statistics } \\
\hline \multirow{2}{*}{ Nilai } & Kelas & N & Mean & $\begin{array}{c}\text { Std. } \\
\text { Deviation }\end{array}$ & $\begin{array}{c}\text { Std. Error } \\
\text { Mean }\end{array}$ \\
\cline { 2 - 6 } & Kelas H & 26 & 82.5000 & 6.10082 & 1.19647 \\
\hline
\end{tabular}

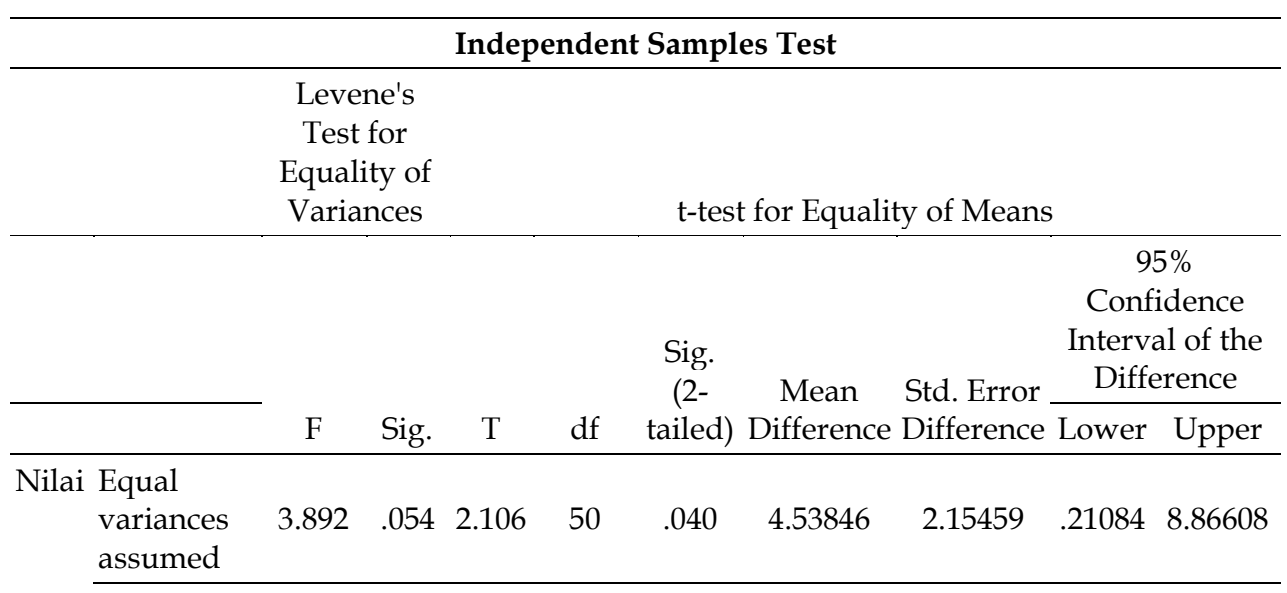




\begin{tabular}{|c|c|c|c|c|c|c|c|c|c|}
\hline \multicolumn{10}{|c|}{ Independent Samples Test } \\
\hline & $\begin{array}{r}\text { Leve } \\
\text { Tes } \\
\text { Equa } \\
\text { Varic }\end{array}$ & $\begin{array}{l}\text { ne's } \\
\text { for } \\
\text { ity of } \\
\text { nces }\end{array}$ & \multicolumn{7}{|c|}{ t-test for Equality of Means } \\
\hline & \multirow[b]{2}{*}{$\mathrm{F}$} & \multirow[b]{2}{*}{ Sig. } & \multirow[b]{2}{*}{$\mathrm{T}$} & \multirow[b]{2}{*}{ df } & \multirow{2}{*}{$\begin{array}{l}\text { Sig. } \\
(2- \\
\text { tailed) }\end{array}$} & \multirow{2}{*}{$\begin{array}{c}\text { Mean } \\
\text { Difference }\end{array}$} & \multirow{2}{*}{$\begin{array}{l}\text { Std. Error } \\
\text { Difference }\end{array}$} & $\begin{array}{r}\text { Con } \\
\text { Inter } \\
\text { Dif } \\
\end{array}$ & $\begin{array}{l}5 \% \\
\text { fidence } \\
\text { al of the } \\
\text { erence }\end{array}$ \\
\hline & & & & & & & & Lowe & Upper \\
\hline $\begin{array}{l}\text { Nilai Equal } \\
\text { variances } \\
\text { assumed }\end{array}$ & 3.892 & .054 & 2.106 & 50 & .040 & 4.53846 & 2.15459 & .21084 & 8.86608 \\
\hline $\begin{array}{l}\text { Equal } \\
\text { variances } \\
\text { not } \\
\text { assumed }\end{array}$ & & & 2.106 & 43.596 & .041 & 4.53846 & 2.15459 & .19504 & 8.88188 \\
\hline
\end{tabular}

d. Angket Siswa

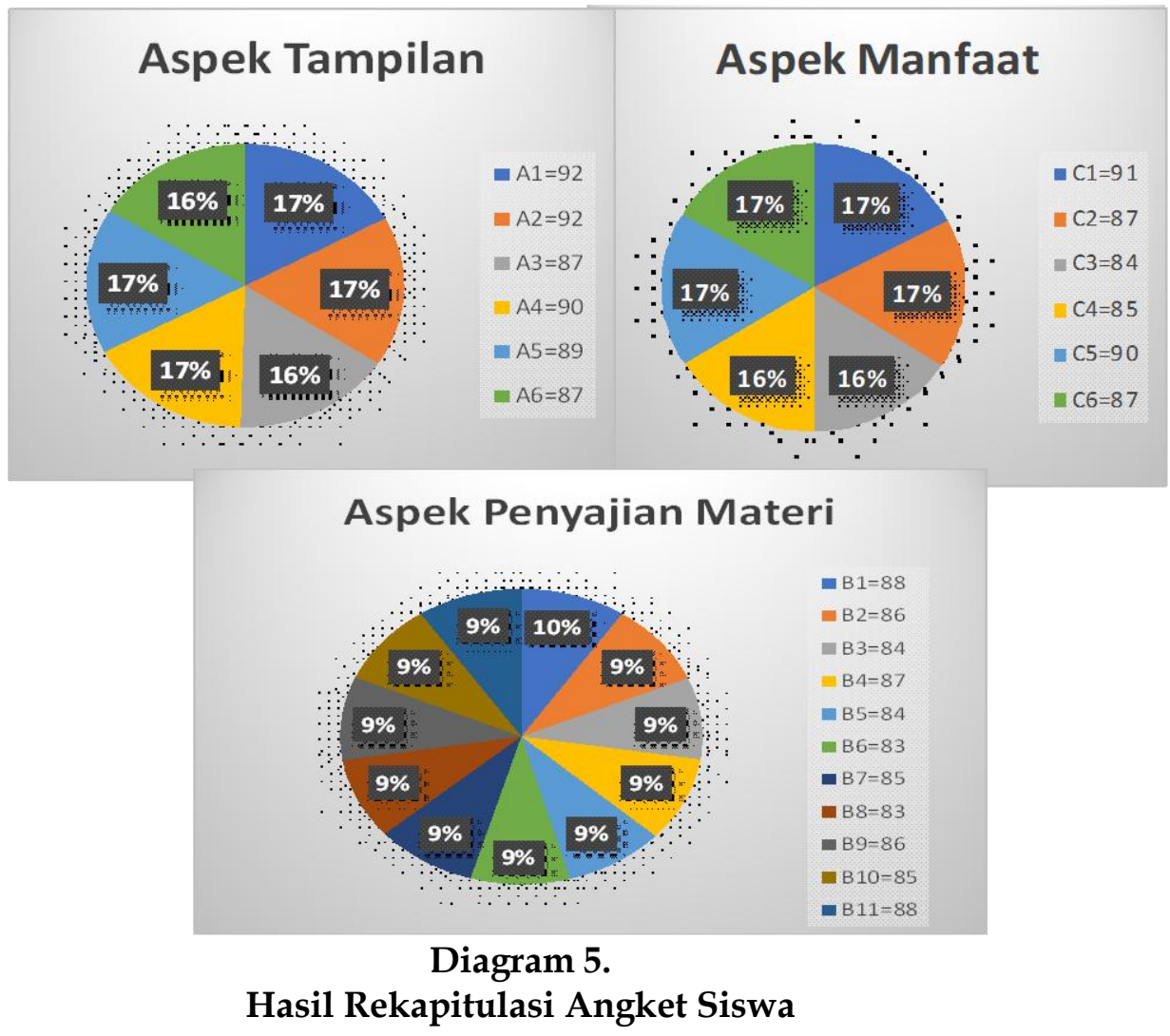




\section{Analisis Data Hasil Aplikasi Praktis Inovasi Pembelajaran}

Teknik analisis data kuantitatif digunakan untuk menganalisis data numerik berupa skor yang diperoleh dari angket penilaian. Pengolahan data angket diperoleh dari penyebaran angket kepada subjek ahli dan angket kepada subjek praktisi/guru yang sudah divalidasi. Data numerik yang didapat kemudian dihitung dengan rumus berikut.

$$
P=\frac{\sum X}{\sum X 1} \times 100 \%
$$

Keterangan

$\mathrm{P} \quad$ : persentase yang dicari

$\sum \mathrm{X} \quad$ : total jawaban responden dalam satu item

$\sum X 1$ : jumlah jawaban ideal dalam 1 item

100 : bilangan konstan

Setelah perhitungan untuk seluruh data numerik selesai dilakukan pada masing-masing angket subjek uji, persentase yang diperoleh dikelompokkan pada kriteria tertentu sehingga diketahui tingkat kelayakan produk. Kriteria kelayakan berdasarkan persentase yang didapat, dikelompokan sesuai tabel 5

Tabel 5.

Kualifikasi Hasil Uji Produk

\begin{tabular}{cccc}
\hline $\begin{array}{c}\text { Nilai Tiap } \\
\text { Kriteria }\end{array}$ & Persentase & Kualifikasi & Tindak Lanjut \\
\hline 4 & $85 \%-100 \%$ & Sangat layak & Implementasi \\
\hline 3 & $75 \%-84 \%$ & Layak & Implementasi \\
\hline 2 & $55 \%-74 \%$ & Kurang layak & Revisi \\
\hline 1 & $<55 \%$ & Tidak layang & Revisi \\
\hline
\end{tabular}

Keterangan:

a. Apabila media yang diuji tersebut mencapai tingkat persentase $85 \%$ $100 \%$, media tersebut dapat diimplementasikan secara langsung tanpa adanya revisi 
b. Apabila media yang diuji tersebut mencapai tingkat persentase $75 \%$ $84 \%$, media tersebut dapat diimplementasikan dengan melakukan sedikit revisi

c. Apabila media yang diuji tersebut mencapai tingkat persentase $55 \%$ $74 \%$, media tersebut harus direvisi sesuai dengan catatan ahli dan praktisi terlebih dahulu baru diimplementasikan

d. Apabila media yang diuji tersebut mencapai tingkat persentase $<55 \%$, media tersebut tergolong harus direvisi secara menyeluruh mengenai isi produk baru kemudian diimplementasikan

Berikut ini akan dipaparkan hasil analisis uji validasi ahli media dan ahli materi beserta analisis hasil uji coba media.

\section{Analisis Data Hasil Uji Validasi Ahli Media}

Berdasarkan Diagram 1 Penyajian Data Hasil Uji Validasi Ahli Media, diketahui penilaian aspek rekayasa perangkat lunak dan tampilan visual serta audio meliputi 17 komponen indikator. Total skor nilai yang diberikan V1 dan V2 adalah 120 dari jumlah total skor 136. Dari nilai tersebut dapat dihitung persentase kelayakan dengan rumus berikut.

$$
\begin{aligned}
& P=\frac{120}{136} \times 100 \% \\
& P=88 \%
\end{aligned}
$$

Berdasarkan rumus di atas, dapat diketahui persentase kelayakan aspek rekayasa perangkat lunak dan tampilan visual serta audio dari ahli media memperoleh nilai sebesar 88 \%. Nilai ini berarti bahwa Media Pembelajaran Unggah-Ungguh Kenali Mainkan Kreasi berbasis Android sangat layak untuk diimplementasikan.

\section{Analisis Data Hasil Uji Validasi Ahli Materi}

Berdasarkan diagram 2 Penyajian Data Hasil Uji Validasi Ahli Materi, diketahui penilaian aspek isi, penyajian, dan bahasa yang meliputi 13 komponen indikator. Total skor nilai yang diberikan V3 dan V4 adalah 
89 dari jumlah total skor 104. Dari nilai tersebut dapat dihitung persentase kelayakan dengan rumus berikut.

$$
\begin{aligned}
& P=\frac{86}{104} \times 100 \% \\
& P=82 \%
\end{aligned}
$$

Berdasarkan rumus di atas, dapat diketahui persentase kelayakan aspek isi, penyajian, dan bahasa dari ahli media memperoleh nilai sebesar 82 \%. Nilai ini berarti bahwa Media Pembelajaran Unggah-Ungguh Kenali Mainkan Kreasi berbasis Android layak untuk diimplementasikan.

\section{Analisis Data Hasil Uji Coba Media}

\section{a. Uji Prasyarat Analisis Data}

Dalam uji normalitas, diketahui syarat data berdistribusi normal jika nilai signifikansi lebih besar dari 0,05 maka data tersebut berdistribusi normal. Sebaliknya, jika nilai signifikansi lebih kecil dari 0,05 maka data tersebut tidak berdistribusi normal. Berdasarkan Tabel 3.1, diketahui bahwa signifikansi data yang dimiliki adalah 0,830. Nilai signifikansi ini lebih besar dari 0,05. Dengan demikian, berarti data prates dan pascates kelas kontrol (8.1) dan kelas eksperimen (8.5) berdistribusi normal.

Berdasarkan Tabel 2, diketahui bahwa signifikansi data yang dimiliki adalah 0,829. Nilai signifikansi ini lebih besar dari 0,05. Dengan demikian, berarti data pascates kelas kontrol (8.1) dan kelas eksperimen (8.5) berdistribusi normal.

Berdasarkan Tabel 3, diketahui bahwa signifikansi data yang dimiliki adalah 0,960. Nilai signifikansi ini lebih besar dari 0,05. Dengan demikian, berarti data prates kelas kontrol (8.1) dan kelas eksperimen (8.5) homogen. Selain itu, juga diketahui bahwa signifikansi data yang dimiliki adalah 0,464. Nilai signifikansi ini lebih besar dari 0,05. Dengan demikian, berarti data pascates kelas kontrol (8.1) dan kelas eksperimen (8.5) homogen. 


\section{b. Uji Beda Penggunaan Media}

Berdasarkan tabel 4 di atas, dapat diketahui bahwa $t$ hitung $>t$ tabel dan nilai signifikansi $<0,05$. Hal tersebut dibuktikan pada nilai $t$ hitung sebesar 2,106, sedangkan $t$ tabel sebesar 2,101. Jadi $t$ hitung $>t$ tabel $(2,106>2,01)$. Untuk nilai signifikansi, dapat dibuktikan pada kolom sig. (2-tailed), yaitu sebesar 0,040 sehingga dapat dibuktikan nilai sig. < 0,05 . Nilai $t$ hitung positif yang berarti rata-rata nilai kelas eksperimen lebih tinggi daripada kelas kontrol.

Pada tabel 4 group statistic terlihat rata-rata untuk kelas eksperimen adalah 82,5 dan kelas kontrol adalah 77,9. Hal ini membuktikan bahwa rata-rata nilai kelas eksperimen lebih tinggi daripada kelas kontrol. Perbedaan rata-rata (mean diference) diketahui sebesar 4,6. Nilai tersebut diperoleh dari 82,5-77,9. Perbedaan berkisar 0,21 sampai 8,86. Nilai tersebut tertera pada kolom lower dan upper. Dengan demikian, dapat ditarik kesimpulan bahwa Ho ditolak dan H1 diterima, artinya bahwa ada perbedaan signifikan rata-rata nilai antara kelas kontrol dan kelas eksperimen.

\section{c. Analisis Angket Siswa}

Berikut ini akan disajikan analisis data setiap aspek yang diisi siswa dalam angket.

\section{1) Aspek Tampilan}

Penilaian yang diberikan seluruh siswa $\left(\sum x\right)$ berupa angka pada aspek tampilan berjumlah 537 dengan jumlah maksimal $\left(\sum \times 1\right)$ pada aspek ini adalah 624. Kedua skor ini digunakan untuk menentukan kelayakan persentase $(P)$ dengan rumus sebagai berikut.

$$
\begin{aligned}
& P=\frac{537}{624} \times 100 \% \\
& \mathrm{P}=86 \%
\end{aligned}
$$

Berdasarkan rumus di atas, dapat diketahui nilai kelayakan aspek tampilan oleh siswa mendapat $86 \%$. Nilai tersebut menunjukkan bahwa aspek tampilan dari Multimedia Teks Wawanrembug berbasis Blended Learning yang dikembangkan tergolong sangat layak digunakan oleh siswa. 


\section{2) Aspek Penyajian Materi}

Penilaian yang diberikan seluruh siswa $\left(\sum x\right)$ berupa angka pada aspek penyajian materi berjumlah 939 dengan jumlah maksimal $\left(\sum \times 1\right)$ pada aspek ini adalah 1144. Kedua skor ini digunakan untuk menentukan kelayakan persentase $(\mathrm{P})$ dengan rumus sebagai berikut.

$$
\begin{aligned}
& P=\frac{939}{1144} \times 100 \% \\
& \mathrm{P}=82 \%
\end{aligned}
$$

Berdasarkan rumus di atas, dapat diketahui nilai kelayakan aspek penyajian materi oleh siswa mendapat $82 \%$. Nilai tersebut menunjukkan bahwa aspek penyajian materi dari Multimedia Teks Wawanrembug berbasis Blended Learning yang dikembangkan tergolong layak digunakan oleh siswa.

\section{3) Aspek Manfaat}

Penilaian yang diberikan seluruh siswa $\left(\sum x\right)$ berupa angka pada aspek manfaat berjumlah 524 dengan jumlah maksimal $\left(\sum x 1\right)$ pada aspek ini adalah 624. Kedua skor ini digunakan untuk menentukan kelayakan persentase $(\mathrm{P})$ dengan rumus sebagai berikut.

$$
\begin{aligned}
& P=\frac{524}{624} \times 100 \% \\
& \mathrm{P}=84 \%
\end{aligned}
$$

Berdasarkan rumus di atas, dapat diketahui nilai kelayakan aspek manfaat oleh siswa mendapat $84 \%$. Nilai tersebut menunjukkan bahwa aspek manfaat dari Multimedia Teks Wawanrembug berbasis Blended Learning yang dikembangkan tergolong layak digunakan oleh siswa.

Dengan melihat ketiga aspek di atas, dapat diketahui bahwa persentase kelayakan total dari media yang dikembangkan adalah sebesar 83\%. Dengan demikian dapat disimpulkan bahwa dari angket siswa Multimedia Teks Wawanrembug berbasis Blended Learning yang dikembangkan tergolong layak untuk digunakan.

Untuk memudahkan pemahaman dan pembacaan, hasil penelitian dideskripsikan terlebih dahulu baru dilanjutkan dengan pembahasan. 
Subjudul hasil dan subjudul pembahasan disajikan terpisah. Bagian ini harus menjadi bagian yang paling banyak, minimum $60 \%$ dari keseluruhan badan artikel.

\section{Penutup}

Berdasarkan data dan pembahasan yang telah diperoleh selama proses pembelajaran, dapat ditarik simpulan bahwa Multimedia Teks Wawanrembug berbasis Blended Learning termasuk kategori layak diimplementasikan dalam pembelajaran keterampilan unggah-ungguh basa. Selain itu multimedia Teks Wawanrembug berbasis Blended Learning terbukti efektif dapat meningkatkan keterampilan unggah-ungguh basa siswa dengan ketuntasan belajar siswa meningkat.

\section{Ucapan Terimakasih}

Ucapan terima kasih disampaikan kepada Kepala Dinas Pendidikan, Pemuda dan Olahraga Kota Probolinggo, Kepala SMPN 8 Kota Probolinggo, Pengawas Guru Kota Probolinggo, dan rekan-rekan guru di SMPN 8 Kota Probolinggo yang telah membantu dan memberikan kesempatan sehingga saya dapat menulis artikel ilmiah ini dan mengikuti lomba guru berprestasi.

\section{Daftar Referensi}

Adipitoyo, S. (2018). Pasinaon Basa Jawi: Lelandhesan Paradigmatis lan Wawasan Strategis. Surabaya: Sahabat Mandiri.

Fishman, J. (2000). Language, Ethnicity, and Intergroup Relations. . London: Academic Press.

Hasan, M. \&., \& Iqbal. (2013). Analisis Data Penelitian dengan Statistik Edisi Kedua. . Jakarta: PT Bumi Aksara.

Husamah. (2014). PEMBELAJARAN BAURAN (BLENDED LEARNING) Terampil Memadukan Keunggulan Pembelajaran Face-To-Face, Elearning Offline-Online, dan Mobile Learning. Jakarta: Prestasi Pustaka.

J. Rotherdam, A., \& Willingham, D. (2009). 21st Century Skills: The Challenges Ahead. Educational Leadership Volume 67 Number 1, 16-21. 
Mustikasari, A. (2017, November 19). Berbagai Jenis Media Pembelajaran. Diakses 19 November 2017, dari . 2014, hal. https://edunursing.com/berbagai-jenis-media-pembelajaran/ 50.

Peraturan Gubernur Jawa Timur Nomor 19. (2014, April 3). Mata Pelajaran Bahasa Daerah sebagai Muatan Lokal Wajib di Sekolah/Madrasah. 19, hal. 19.

Peraturan Menteri Pendidikan Nasional Nomor 16 Tahun 2007. (2007, mei 4). Standar Kualifikasi dan Kompetensi Guru. 16, hal. Lembaran Negara Republik Indonesia Tahun 2007.

Peraturan Pemerintah Nomor 19 Tahun 2005 Standar Pendidikan Nasional. (2005, mei 16). . 16 Mei 2005. Jakarta. 16, hal. Lembaran Negara Republik Indonesia Tahun 2005 Nomor 41.

Sadiman, A. S. (2010). Media Pendidikan: Pengertian, Pengembangan, dan Pemanfaatannya. Jakarta: Rajawali Pers.

Sari, M. (2016). Blended Learning, Model Pembelajaran Abad Ke-21 Di Perguruan Tinggi. Ta'dib, Jurnal Fakultas Pendidikan dan Pelatihan Guru, 126-136.

Sasangka, S. S. (2004). Unggah-ungguh Bahasa Jawa. Jakarta: Yayasan Paramalingua.

Siswanto, R., Sugiono, S., \& Prasojo, L. (2018). The Development of Management Model Program of Vocational School Teacher Partnership with Business World and Industry Word (DUDI). Jurnal Ilmiah Peuradeun, 6(3), 365-384. doi:10.26811/peuradeun.v6i3.322.

Thiagarajan, S. (1974). Instructional Development for Training Teacher of Exceptional Children. . Minnesota: The Council for Exceptional Children.

Undang-Undang Nomor 20 Tahun 2003 Sistem Pendidikan Nasional. (2003, Juli 8). Undang-Undang Nomor 20 Tahun 2003 Sistem Pendidikan Nasional. hal. Lembaran Negara Republik Indonesia Tahun 2003.

Wibawa, S. (2004). Buku Pegangan Kuliah Mata Pelajaran Bahasa Jawa. Yogyakarta: Fakultas Ilmu Pendidikan UNY.

Wibawanto, W. (2017). Desain dan Pemrogaman Multimedia Pembelajaran Interaktif. Jember: Penerbit Cerdas Ulet Kreatif. 